\title{
MECHANIZMUSOK OPTIMÁLIS KIEGYENSÚLYOZÁSÁNAK ELMÉLETE
}

\section{THE THEORY OF OPTIMAL BALANCING OF MECHANISMS}

\author{
Papp István, ${ }^{1}$ Máté Márton ${ }^{2}$ \\ Sapientia Erdélyi Magyar Tudományegyetem, Marosvásárhelyi Kar, Gépészmérnöki Tanszék, \\ Marosvásárhely, Románia \\ ${ }^{1}$ pappistvan1944@yahoo.com \\ ${ }^{2}$ mmate@ms.sapientia.ro
}

\begin{abstract}
This paper presents a general theory regarding the balancing of mechanisms. It starts with Stevenson's theory [1], which proves that any mechanism can be dynamically perfectly balanced if there is a pair of counterweights that are eccentrically positioned in three reciprocating perpendicular axes, passing through the mass center of the body. The system of inertial forces are extended in Fourier series where only the first terms, the basic harmonics, are considered. The proposed goal is to stultify the effect of inertial forces and torques. This paper deals with a situation more appropriate to reality. In common cases there doesn't exist the possibility of implementing counterweights in three perpendicular axes. In this situation only the minimization of inertial forces and torques remains as a possible solution. The method developed for this case is presented.
\end{abstract}

Keywords: mechanism, balancing, optimization.

\section{Összefoglalás}

Jelen közlemény a mechanizmusok dinamikus kiegyensúlyozását megoldó, általános érvényességű elméletet mutat be. A kiindulási pont a Stevenson-féle elmélet, melyben a szerző igazolja, hogy a teljes kiegyensúlyozáshoz három, kölcsönösen merőleges, a géptörzs súlypontján áthaladó tengelyre körhagyással illesztett ellensúly szükséges. A géptörzshöz viszonyított tehetetlenségi erők rendszerét Fourier-féle sorbafejtéssel rendszerezi, majd az alapharmonikusok hatásának nullázását tűzi ki célul. Jelen közleményben azt a valósághoz közelebb álló helyzetet tárgyaljuk, amikor nincsen lehetőség a három kölcsönösen merőleges kiegyensúlyozó tengely definiálására, illetve a megfelelő ellensúlyok beépítésére. Ez esetben a gerjesztő tehetetlenségi erőrendszer hatását minimalizálni lehet. Jelen dolgozat ez utóbbi esetre kidolgozott módszert mutatja be.

Kulcsszavak: mechanizmus, kiegyensúlyozás, optimalizálás.

\section{A teljes kiegyensúlyozás matemati- kai modellje}

E. N. Stevensen Jr., egyik tudományos közleményében egy új, általánosított módszert mutat be [1], amely bármely mechanizmus kiegyensúlyozására alkalmazható. Bizonyítja, hogy bármely mechanizmus kiegyensúlyozható hat ellensúly beiktatásával, amennyiben ezek három olyan, egymásra kölcsönösen merőleges tengelyre illeszkednek, amelyek a gép törzsének súlypontjába helyezett azon koordináta-rendszer tengelyeivel párhuzamosak, amely szerint a géptörzset terhelő erőket és nyomatékokat kiszámolták. Azokban a sajátos helyzetekben, amelyekben a három ellensúlytartó tengely valamelyike hiányzik, a mód- 
szer röviden tárgyalja a géptörzs valamely pontjában ébredő rezgés amplitúdójának minimalizálását. Itt szükséges megjegyezni, hogy a közlemény amellett, hogy csupán egyetlen csomópont rezgésamplitúdójának minimalizálását tárgyalja, azt is igazolja, hogy a megvalósuló minimalizálás mellett a gép többi pontjában a rezgések amplitúdói növekednek.

Annak ellenére, hogy a Stevenson-féle módszer nem kínál megoldást a géptörzs összes pontjában ébredő rezgések amplitúdóinak minimalizálására, kiemelkedő a szakirodalomban eddig megjelent, a dinamikai kiegyensúlyozást tárgyaló közlemények közül, amely referenciapontként tekinthető és a továbbfejlesztés lehetőségével bír.

A következőkben a dinamikus kiegyensúlyozást az 1. ábrán szemléltetett általános mechanikai modellen vizsgáljuk.

Az OXYZ koordináta-rendszer origója egybeesik a géptörzs súlypontjával. Az $O X$ koordinátatengellyel párhuzamos kiegyensúlyozó tengely az $O Y Z$ síkot a $\left(0, a_{z}, a_{y}\right)$ koordinátájú pontban metszi. Erre a kiegyensúlyozó tengelyre illesztett ellensúlyok szabadon választott abszcisszái $X=a_{1}$ és $X=a_{2}$. Hasonlóképpen az $O Y$ koordinátatengelylyel párhuzamos kiegyensúlyozó tengely az $O X Z$ síkot a $\left(b_{z}, 0, b_{x}\right)$ koordinátájú pontban metszi, a ráillesztett ellensúlyok ordinátái pedig, az előbbi egyezménnyel azonos módon, $Y=b_{1}$ és $Y=b_{2}$ lesznek. Végül, az $O Z$ koordinátatengellyel párhuzamos kiegyensúlyozó tengely az $O X Y$ síkot a $\left(c_{y}, c_{x}, 0\right)$ pontban metszi, a hozzárendelt ellensúlyok helyzetei pedig a $Z=c_{1}$ és $Z=c_{2}$ koordinátákkal vannak jelölve.

Az excentrikus elhelyezésű kiegyensúlyozó tömegek által létrehozott centrifugális erők abszolút értékét $\mathrm{az}$

$$
F=m \omega^{2} r
$$

képlettel számítjuk, ahol $m$ a tömeg, $r$ pedig a tömeg súlypontja és a forgástengely közötti távolság. A kiegyensúlyozó erőket két alsó indexszel látjuk el: az első a tömegek illeszkedési tengelyét, míg a második a tömegek megnevezését jelenti. Ezzel a jelöléssel az $O X$ tengellyel párhuzamos kiegyensúlyozó tengelyen az $F_{x 1}$ és $F_{x 2}$, az $O Y$ tengellyel párhuzamos tengelyen az $F_{y 1}$ és $F_{y 2}$, míg az $O Z$ tengellyel párhuzamos tengelyen az $F_{z 1}$ és $F_{z 2}$ centrifugális erők keletkeznek.

A továbbiakban szükség lesz arra, hogy az excentrikusan elhelyezett kiegyensúlyozó tömeg súlypontjának helyzetét a géptörzshöz kötött,

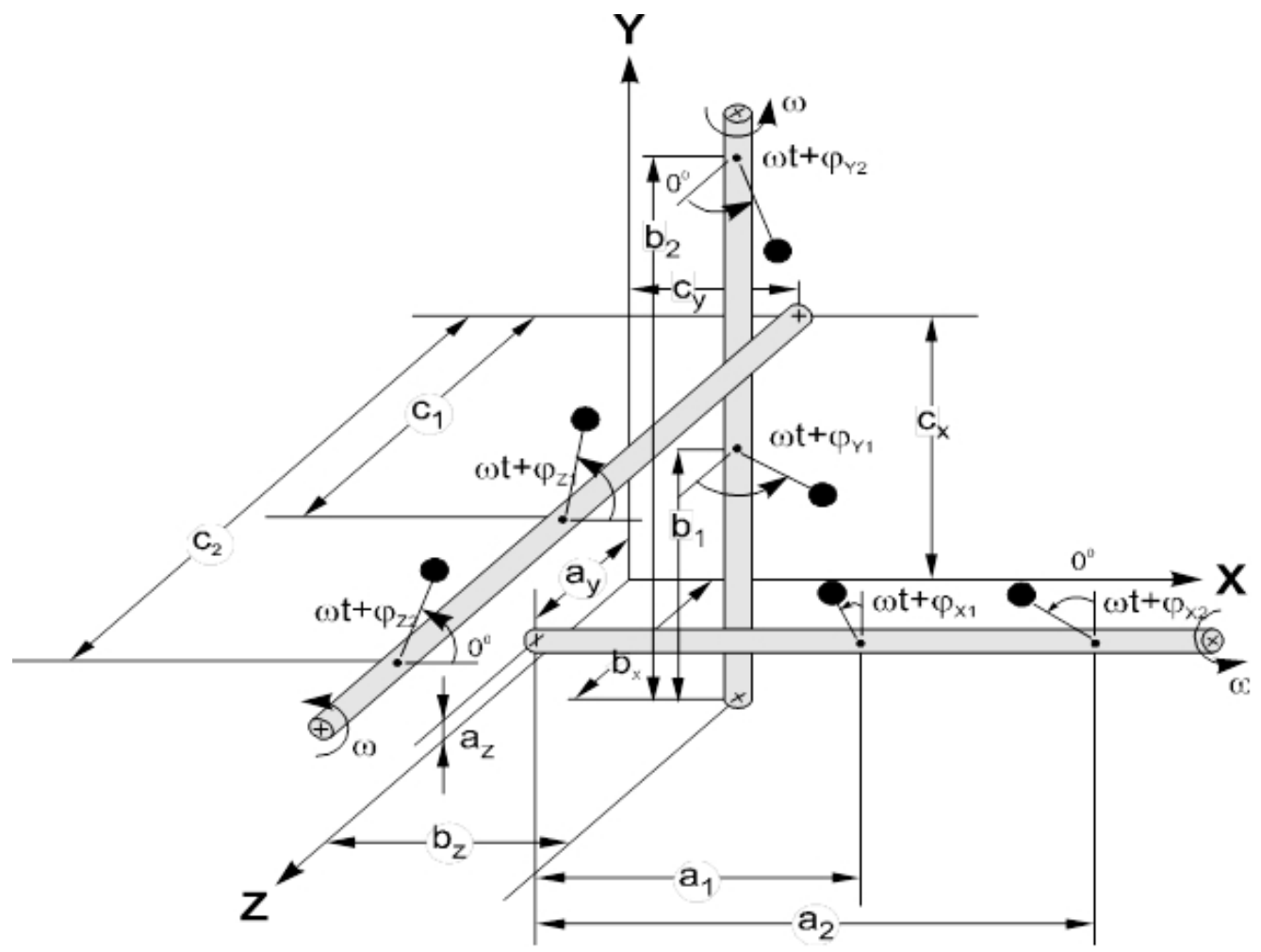

1. ábra. A dinamikus kiegyensúlyozás általánosított mechanikai modellje 
helytálló koordináta-rendszerhez viszonyítani tudjuk. Nevezzük a következőkben fázisszögnek azt a szöget, amelyet a kiegyensúlyozó tömeg súlypontjából, a kiegyensúlyozó tengelyre bocsátott merőleges zár be a fennmaradt két merőleges irány valamelyikével. Ily módon az $X$ tengelyre szerelt kiegyensúlyozó tömeg fázisszögét az $Y$ tengelyhez, az $Y$ tengelyre szerelt tömegét a $Z$ tengelyhez, míg a $Z$ tengelyre illesztettét az $X$ tengelyhez viszonyítjuk.

Ahhoz, hogy a kiegyensúlyozást létrehozzuk a tömegek szabadon választott elhelyezésének függvényében, ki kell számítanunk minden kiegyensúlyozó tömeg fázisszögét és a kiegyensúlyozó tengelyhez viszonyított statikus nyomatékát az $O X Y Z$ koordináta-rendszerhez viszonyítva. $\mathrm{Az}$ 1. ábrán szereplő kiegyensúlyozó tömegek pillanatnyi szöghelyzetét az $\omega t+\phi$ kifejezéssel adhatjuk meg, ahol $\phi$-vel a fázisszöget jelöltük.

A Stevenson-féle módszer a Fourier-sorba fejtett erők és nyomatékok első tagjai szerinti, tehát az első harmonikusak teljes kiegyensúlyozást tárgyalja, de az elv alkalmazható bármely harmonikusra.

Az első harmonikus tag a kiegyensúlyozatlan erőket és nyomatékokat $A \cos \omega t+B \sin \omega t$ alakban tartalmazza. Az A és B együtthatók irányokat, erőket és nyomatékokat megkülönböztető indexszel vannak ellátva.

A kinetostatikus elvnek (a D’Alembert-féle elvnek) megfelelően a lengést gerjesztő erők és nyomatékok vektorkettőse a kiegyensúlyozó tömegek által gerjesztett erők és nyomatékok vektorkettősének ellentettje kell hogy legyen. Az eredő erők kiegyenlítéséből az alábbi egyenletrendszert kapjuk:

$$
\begin{aligned}
& \sum F_{X}=0 ; A_{F X} \cos \omega t+B_{F X} \sin \omega t+ \\
& +F_{Z 1} \cos \left(\omega t+\varphi_{Z 1}\right)+F_{Z 2} \cos \left(\omega t+\varphi_{Z 2}\right)+ \\
& +F_{Y 1} \sin \left(\omega t+\varphi_{Y 1}\right)+F_{Y 2} \sin \left(\omega t+\varphi_{Y 2}\right)=0 \\
& \sum F_{y}=0 ; A_{F Y} \cos \omega t+B_{F Y} \sin \omega t+ \\
& +F_{X 1} \cos \left(\omega t+\varphi_{X 1}\right)+F_{X 2} \cos \left(\omega t+\varphi_{X 2}\right)+ \\
& +F_{Z 1} \sin \left(\omega t+\varphi_{Z 1}\right)+F_{Z 2} \sin \left(\omega t+\varphi_{Z 2}\right)=0 \\
& \sum F_{Z}=0 ; A_{F Z} \cos \omega t+B_{F Z} \sin \omega t+ \\
& +F_{Y 1} \cos \left(\omega t+\varphi_{Y 1}\right)+F_{Y 2} \cos \left(\omega t+\varphi_{Y 2}\right)+ \\
& +F_{X 1} \sin \left(\omega t+\varphi_{X 1}\right)+F_{X 2} \sin \left(\omega t+\varphi_{X 2}\right)=0
\end{aligned}
$$

Az eredő nyomatékok kiegyenlítéséből kapjuk a nyomatékok egyenletrendszerét: $\sum M_{x}=0$;

$A_{M X} \cos \omega t+B_{M X} \sin \omega t+b_{1} F_{Y 1} \cos \left(\omega t+\varphi_{Y 1}\right)$

$+b_{2} F_{Y 2} \cos \left(\omega t+\varphi_{Y 2}\right)-c_{1} F_{Z 1} \sin \left(\omega t+\varphi_{Z 1}\right)-$

$-c_{2} F_{Z 2} \sin \left(\omega t+\varphi_{Z 2}\right)-a_{y} F_{X 1} \cos \left(\omega t+\varphi_{X 1}\right)-$

$-a_{y} F_{X 2} \cos \left(\omega t+\varphi_{X 2}\right)+a_{z} F_{X 1} \sin \left(\omega t+\varphi_{X 1}\right)+$

$+a_{z} F_{X 2} \sin \left(\omega t+\varphi_{X 2}\right)=0$

$\sum M_{y}=0$

$A_{M Y} \cos \omega t+B_{M Y} \sin \omega t+c_{1} F_{Z 1} \cos \left(\omega t+\varphi_{Z 1}\right)+$

$+c_{2} F_{Z 2} \cos \left(\omega t+\varphi_{Z 2}\right)-a_{1} F_{X 1} \sin \left(\omega t+\varphi_{X 1}\right)-$

$-a_{2} F_{X 2} \sin \left(\omega t+\varphi_{X 2}\right)-b_{z} F_{Y 1} \cos \left(\omega t+\varphi_{Y 1}\right)-$

$b_{z} F_{Y 2} \cos \left(\omega t+\varphi_{Y 2}\right)+b_{x} F_{Y 1} \sin \left(\omega t+\varphi_{Y 1}\right)+$

$b_{x} F_{Y 2} \sin \left(\omega \cdot t+\varphi_{Y 2}\right)=0$

$\sum M_{Z}=0$;

$A_{M Z} \cos \omega t+B_{M Z} \sin \omega t+a_{1} F_{X 1} \cos \left(\omega t+\varphi_{X 1}\right)+$

$+a_{2} F_{X 2} \cos \left(\omega t+\varphi_{X 2}\right)-b_{1} F_{Y 1} \sin \left(\omega t+\varphi_{Y 1}\right)-$

$-b_{2} F_{Y 2} \sin \left(\omega t+\varphi_{Y 2}\right)+c_{y} F_{Z 1} \sin \left(\omega t+\varphi_{Z 1}\right)+$

$+c_{y} F_{Z 2} \sin \left(\omega t+\varphi_{Z 2}\right)-c_{x} F_{Z 1} \cos \left(\omega t+\varphi_{Z 1}\right)-$

$-c_{x} F_{Z 2} \cos \left(\omega t+\varphi_{Z 2}\right)=0$

Vezessük be a képletek könnyebb érthetősége végett az alábbi jelöléseket:

$$
\begin{aligned}
Q_{1}=F_{X 1} \cos \varphi_{X 1} & Q_{2}=F_{X 2} \cos \varphi_{X 2} \\
R_{1}=F_{X 1} \sin \varphi_{X 1} & R_{2}=F_{X 2} \sin \varphi_{X 2} \\
S_{1}=F_{Y 1} \cos \varphi_{Y 1} & S_{2}=F_{Y 2} \cos \varphi_{Y 2} \\
T_{1}=F_{Y 1} \sin \varphi_{Y 1} & T_{2}=F_{Y 2} \sin \varphi_{Y 2} \\
U_{1}=F_{Z 1} \cos \varphi_{Z 1} & U_{2}=F_{Z 2} \cos \varphi_{Z 2} \\
V_{1}=F_{Z 1} \sin \varphi_{Z 1} & V_{2}=F_{Z 2} \sin \varphi_{Z 2}
\end{aligned}
$$

A (4) jelölések bevezetésével a (2) és (3) egyensúlyegyenletek az alábbi alakot öltik: 
$\sum F_{X}=0 ;\left(A_{F X}+U_{1}+U_{2}+T_{1}+T_{2}\right) \cos \omega t+$ $+\left(B_{F X}-V_{1}-V_{2}+S_{1}+S_{2}\right) \sin \omega t=0$

$\sum F_{y}=0 ;\left(A_{F Y}+Q_{1}+Q_{2}+V_{1}+V_{2}\right) \cos \omega t+$ $+\left(B_{F Y}+U_{1}+U_{2}-R_{1}-R_{2} \sin \omega t=0\right.$

$\sum F_{z}=0 ;\left(A_{F Z}+S_{1}+S_{2}+R_{1}+R_{2}\right) \cos \omega t+$ $+\left(B_{F Z}+Q_{1}+Q_{2}-T_{1}-T_{2}\right) \sin \omega t=0$

$\sum M_{X}=0 ; E_{X 1} \cos \omega t+E_{X 2} \sin \omega t=0$

$\sum M_{y}=0 ; E_{Y 1} \cos \omega t+E_{Y 2} \sin \omega t=0$

$\sum M_{Z}=0 ; E_{Z 1} \cos \omega t+E_{Z 2} \sin \omega t=0$

$E_{X 1}=\left(A_{M X}+b_{1} S_{1}+b_{2} S_{2}-c_{1} V_{1}-c_{2} V_{2}-\right.$

$$
\begin{gathered}
\left.-a_{y} Q_{1}-a_{y} Q_{2}+a_{z} R_{1}+a_{z} R_{2}\right) \\
E_{X 2}=\left(B_{M X}-b_{1} T_{1}-b_{2} T_{2}-c_{1} U_{1}-c_{2} U_{2}+\right. \\
\left.+a_{z} Q_{1}+a_{z} Q_{2}+a_{y} R_{1}+a_{y} R_{2}\right) \\
E_{Y 1}=\left(A_{M Y}-a_{1} R_{1}-a_{2} R_{2}+c_{1} U_{1}+c_{2} U_{2}-\right. \\
\left.-b_{z} S_{1}-b_{z} S_{2}+b_{x} T_{1}+b_{x} T_{2}\right) \\
E_{Y 2}=\left(B_{M Y}-c_{1} V_{1}-c_{2} V_{2}-a_{1} Q_{1}-a_{2} Q_{2}+\right. \\
\left.+b_{z} T_{1}+b_{z} T_{2}+b_{x} S_{1}+b_{x} S_{2}\right) \\
E_{Z 1}=\left(A_{M Z}+a_{1} Q_{1}+a_{2} Q_{2}-b_{1} T_{1}-b_{2} T_{2}+\right. \\
\left.c_{y} V_{1}+c_{y} V_{2}-c_{x} U_{1}-c_{x} U_{2}\right) \\
E_{Z 2}=\left(B_{M Z}-a_{1} R_{1}-a_{2} R_{2}-b_{1} S_{1}-b_{2} S_{2}+\right. \\
\left.c_{y} U_{1}+c_{y} U_{2}+c_{x} V_{1}+c_{x} V_{2}\right)
\end{gathered}
$$

Ahhoz, hogy a mechanizmus kiegyensúlyozását a teljes kinematikai ciklusra megvalósítsuk, az (5) egyenletrendszernek a $t$ időparaméter bár- mely értékére teljesülnie kell. Ez csak akkor valósulhat meg, ha a rendszer minden egyenletében a $\cos \omega t$ és a sin $\omega t$ együtthatóit nullával egyenlővé tesszük. Ezzel a feltétellel egy 12 egyenletből álló és 12 ismeretlent tartalmazó lineáris egyenletrendszert kapunk, melynek mátrixos alakja a (6) egyenletrendszerben írható fel.

Az egyenletrendszer megoldása után, a (4) képletekből kifejezzük a kiegyensúlyozó erők abszolút értékeit (7).

Ugyancsak a (4) egyenletekből számítjuk ki a kiegyensúlyozó erők fázisszögeit is, azaz a (8) egyenleteket.

$$
\begin{aligned}
& F_{X 1}=\sqrt{Q_{1}^{2}+R_{1}^{2}}=(m r)_{X 1} \omega^{2} \\
& F_{X 2}=\sqrt{Q_{2}^{2}+R_{2}^{2}}=(m r)_{X 2} \omega^{2} \\
& F_{Y 1}=\sqrt{S_{1}^{2}+T_{1}^{2}}=(m r)_{Y 1} \omega^{2} \\
& F_{Y 2}=\sqrt{S_{2}^{2}+T_{2}^{2}}=(m r)_{Y 2} \omega^{2} \\
& F_{Z 1}=\sqrt{U_{1}^{2}+V_{1}^{2}}=(m r)_{Z 1} \omega^{2} \\
& F_{Z 2}=\sqrt{U_{2}^{2}+V_{2}^{2}}=(m r)_{Z 2} \omega^{2} \\
& \phi_{X i}=\operatorname{arctg} \frac{R_{i}}{Q_{i}} \\
& \phi_{Y i}=\operatorname{arctg} \frac{T_{i}}{S_{i}} \\
& \phi_{Z i}=\operatorname{arctg} \frac{V_{i}}{U_{i}}, i \in\{1 ; 2\}
\end{aligned}
$$

$$
\left[\begin{array}{cccccccccccc}
0 & 0 & 0 & 0 & 0 & 0 & 1 & 1 & 1 & 1 & 0 & 0 \\
0 & 0 & 0 & 0 & 1 & 1 & 0 & 0 & 0 & 0 & -1 & -1 \\
1 & 1 & 0 & 0 & 0 & 0 & 0 & 0 & 0 & 0 & 1 & 1 \\
0 & 0 & -1 & -1 & 0 & 0 & 0 & 0 & 1 & 1 & 0 & 0 \\
0 & 0 & 1 & 1 & 1 & 1 & 0 & 0 & 0 & 0 & 0 & 0 \\
1 & 1 & 0 & 0 & 0 & 0 & -1 & -1 & 0 & 0 & 0 & 0 \\
-a_{y} & -a_{y} & a_{z} & a_{z} & b_{1} & b_{2} & 0 & 0 & 0 & 0 & -c_{1} & -c_{2} \\
a_{z} & a_{z} & a_{y} & a_{y} & 0 & 0 & -b_{1} & -b_{2} & -c_{1} & -c_{2} & 0 & 0 \\
0 & 0 & -a_{1} & -a_{2} & -b_{z} & -b_{z} & b_{x} & b_{x} & c_{1} & c_{2} & 0 & 0 \\
-a_{1} & -a_{2} & 0 & 0 & b_{x} & b_{x} & b_{z} & b_{x} & 0 & 0 & -c_{1} & -c_{2} \\
a_{1} & a_{2} & 0 & 0 & 0 & 0 & -b_{1} & -b_{2} & -c_{x} & -c_{x} & c_{y} & c_{y} \\
0 & 0 & -a_{1} & -a_{2} & -b_{1} & -b_{2} & 0 & 0 & c_{y} & c_{y} & c_{x} & c_{x}
\end{array}\right] \cdot\left[\begin{array}{c}
Q_{1} \\
Q_{2} \\
R_{1} \\
R_{2} \\
S_{1} \\
S_{2} \\
T_{1} \\
T_{2} \\
U_{1} \\
U_{2} \\
V_{1} \\
V_{2}
\end{array}\right]=\left[\begin{array}{l}
-A_{F X} \\
-B_{F X} \\
-A_{F Y} \\
-B_{F Y} \\
-A_{F Z} \\
-B_{F Z} \\
-A_{M X} \\
-B_{M X} \\
-A_{M Y} \\
-B_{M Y} \\
-A_{M Z} \\
-B_{M Z}
\end{array}\right]
$$


A (8) egyenletekben lényeges a számláló és a nevező előjelének megtartása, mivel a fázisszöget előjelesen kell számítanunk. (Pozitív az előjel, ha a szöget az óramutató járásával ellentétesen mérjük.)

\section{Optimális kiegyensúlyozás a gép- törzsre ható kiegyensúlyozatlan erők és nyomatékok minimalizálása által}

Abban az esetben, ha a kiegyensúlyozás csak részleges lehet, a kiegyensúlyozatlanul maradt erők és nyomatékok változó abszolút értékei az egész rendszerre kiterjedő rezgéseket gerjesztenek, a mechanizmus működése zajossá válik. Az optimalizálás célja a gép törzsére ható kiegyensúlyozatlan erők és nyomatékok minimalizálása. E módszer alkalmazásával a kiegyensúlyozatlan erők és nyomatékok abszolút értékei a teljes kinematikai ciklus alatt a lehetséges legkisebb értékeket veszik fel.

A kiegyensúlyozatlanul maradt erők és nyomatékok a tehetetlenségi erők, a kiegyensúlyozó erők, illetve ezeknek a géptörzs súlypontjára számított nyomatékai, jelöljük ezeket $\sum F_{X}, \sum F_{Y}, \sum F_{Z}$-vel, illetve $\sum M_{X}, \sum M_{Y}, \sum M_{Z}$-vel. A rezgést okozó tehetetlenségi erőket és ezek nyomatékait Fourier-sorba fejtjük, majd pedig csupán az alapharmonikusokat vesszük tekintetbe:

$$
\begin{aligned}
& \sum F_{x}=A_{\Sigma F_{x}} \cos \omega t+B_{\Sigma F_{x}} \sin \omega t \\
& \sum F_{y}=A_{\Sigma F_{y}} \cos \omega t+B_{\Sigma F_{y}} \sin \omega t \\
& \sum F_{z}=A_{\Sigma F_{z}} \cos \omega t+B_{\Sigma F_{z}} \sin \omega t
\end{aligned}
$$

A (9) egyenletekbeli szereplő $A_{\Sigma F_{k}}, B_{\Sigma F_{k}}, k \in\{X ; Y ; Z\}$ együtthatók formálisan azonosak az (5) egyenletekben szereplő, cos $\omega t$ és sin $\omega t$ zárójelbe foglalt együtthatóival. Itt szükséges nyomatékosítanunk, hogy a zárójelekbe foglalt kifejezések a tehetetlenségi erők, valamint ezek nyomatékainak együtthatói, akár az (5) egyenletekben szereplő $A_{F k}, B_{F K} A_{M k}, B_{M k}, k \in\{X ; Y ; Z\}$ és a kiegyensúlyozó tengelyekre helyezett ellensúlyok által gerjesztett kiegyensúlyozó erők és ezek nyomatékainak együtthatóiból tevődik össze.

Együttesen vizsgálva az (5) és (9) egyenletrendszereket, felírhatjuk az egymásnak megfelelő egyenletek Fourier-együtthatóinak egyenlőségét:

$$
\begin{aligned}
A_{\Sigma F_{X}}= & A_{F X}+U_{1}+U_{2}+T_{1}+T_{2} \\
B_{\Sigma F_{X}}= & B_{F X}-V_{1}-V_{2}+S_{1}+S_{2} \\
A_{\Sigma F_{Y}}= & A_{F Y}+Q_{1}+Q_{2}+V_{1}+V_{2} \\
B_{\Sigma F_{Y}}= & B_{F Y}+U_{1}+U_{2}-R_{1}-R_{2} \\
A_{\Sigma F_{Z}}= & A_{F Z}+S_{1}+S_{2}+R_{1}+R_{2} \\
B_{\Sigma F_{Z}}= & B_{F Z}+Q_{1}+Q_{2}-T_{1}-T_{2} \\
A_{\Sigma M_{X}}= & A_{M X}+b_{1} S_{1}+b_{2} S_{2}-c_{1} V_{1}-c_{2} V_{2}- \\
& -a_{y}\left(Q_{1}+Q_{2}\right)+a_{z}\left(R_{1}+R_{2}\right) \\
B_{\Sigma M_{X}}= & B_{M X}-b_{1} T_{1}-b_{2} T_{2}-c_{1} U_{1}-c_{2} U_{2}+ \\
& +a_{z}\left(Q_{1}+Q_{2}\right)+a_{y}\left(R_{1}+R_{2}\right) \\
A_{\Sigma M_{Y}}= & A_{M Y}-a_{1} R_{1}-a_{2} R_{2}+c_{1} U_{1}+c_{2} U_{2}- \\
& -b_{z}\left(S_{1}+S_{2}\right)+b_{x}\left(T_{1}+T_{2}\right) \\
B_{\Sigma M_{Y}}= & B_{M Y}-c_{1} V_{1}-c_{2} V_{2}-a_{1} Q_{1}-a_{2} Q_{2}+ \\
& +b_{z}\left(T_{1}+T_{2}\right)+b_{x}\left(S_{1}+S_{2}\right) \\
A_{\Sigma M_{Z}}= & A_{M Z}+a_{1} Q_{1}+a_{2} Q_{2}-b_{1} T_{1}-b_{2} T_{2}+ \\
& +c_{y}\left(V_{1}+V_{2}\right)-c_{x}\left(U_{1}+U_{2}\right) \\
B_{\Sigma M_{Z}}= & B_{M Z}-a_{1} R_{1}-a_{2} R_{2}-b_{1} S_{1}-b_{2} S_{2}+ \\
& +c_{y}\left(U_{1}+U_{2}\right)+c_{x}\left(V_{1}+V_{2}\right) \\
&
\end{aligned}
$$

A gép törzsében rezgéseket gerjesztő, kiegyensúlyozatlanul maradt tehetetlenségi erő és nyomaték összetevők Fourier-együtthatóit az

$$
\mathbf{R}_{(i)}=\mathbf{P}_{(i j)} \mathbf{Q}_{(j)}+\mathbf{F}_{(i)}
$$

mátrixegyenlet fejezi ki, amelyben a tagok értelme a következő:

- $\mathbf{R}_{(i)}$ a Fourier-sorba fejtett, optimalizálás után kiegyensúlyozatlanul maradt erők és nyomatékok együtthatóinak $i$ elemű oszlopmátrixa;

- $\mathbf{P}_{(i j)}$ a kiegyensúlyozó erők és tengelyek helyzetét meghatározó, $i$ soros és $j$ oszlopos mátrix;

- $\mathbf{Q}_{(j)}$ az optimális kiegyensúlyozó erők $j$ elemü oszlopmátrixa;

$-\mathbf{F}_{(i)}$ a Fourier-sorba fejtett tehetetlenségi erők és nyomatékok együtthatóinak $i$ elemű oszlopmátrixa.

A továbbiakban a sorok és oszlopok számát jelző indexek használatát mellőzzük.

A (12) egyenletben kéttengelyes kiegyensúlyozás esetében $i=1,2, \ldots, 12$ és $j=1,2, \ldots, 8$, egytengelyes kiegyensúlyozás esetében pedig $i=1,2, \ldots, 10$ és $j=1,2, \ldots, 4$. 
A kiegyensúlyozatlanul maradt erők és nyomatékok minimalizálására az együtthatókat meghatározó függvény kvadratikus alakját használjuk, azaz:

$$
U=\mathbf{R}^{T} \mathbf{R}
$$

Az optimalizálás során a (12) függvény minimum értékét keressük. E célból a függvényt a kiegyensúlyozó erők Q oszlopmátrixának $j$ tagja szerint deriváljuk:

$$
\begin{aligned}
& \frac{\mathrm{d} U}{\mathrm{~d} \mathbf{Q}}=\sum_{k=1}^{j} \frac{\partial U}{\partial Q_{k}}= \\
& =\sum_{k=1}^{j}\left(\left[\frac{\partial \mathbf{R}}{\partial Q_{k}}\right]^{T} \mathbf{R}+\mathbf{R}^{T} \frac{\partial \mathbf{R}}{\partial Q_{k}}\right)
\end{aligned}
$$

Vegyük észre, hogy az $\mathbf{R}$ oszlopmátrixra, valamint parciális deriváltjaira felírhatjuk, hogy

$$
\left[\frac{\partial \mathbf{R}}{\partial Q_{k}}\right]^{T} \mathbf{R}=\mathbf{R}^{T} \frac{\partial \mathbf{R}}{\partial Q_{k}}
$$

Ezzel a (13) egyenlet a következő egyszerübb alakra hozható:

$$
\frac{\mathrm{d} U}{\mathrm{~d} \mathbf{Q}}=2 \sum_{k=1}^{j}\left(\left[\frac{\partial \mathbf{R}}{\partial Q_{k}}\right]^{T} \mathbf{R}\right)=2 \sum_{k=1}^{j}\left(\mathbf{R}^{T} \frac{\partial \mathbf{R}}{\partial Q_{k}}\right)
$$

Felhasználva az R oszlopmátrix (a kiegyensúlyozatlanul maradt erők Fourier-együtthatóinak oszlopmátrixa) (11) mátrixegyenlettel felírt alakját, akkor a $Q_{k}, k=\overline{1 . . j}$ általános erők szerinti parciális deriváltak a következőképpen fejezhetők ki:

$$
\frac{\partial \mathbf{R}}{\partial Q_{k}}=\frac{\partial}{\partial Q_{k}}(\mathbf{P Q}+\mathbf{F})
$$

Mivel a $\mathbf{P}$ és $\mathbf{F}$ oszlopmátrixok nem függnek a $Q_{k}, k=\overline{1 . . j}$ kiegyensúlyozó erőktől, következik, hogy:

$$
\frac{\partial \mathbf{P}}{\partial Q_{k}}=0 ; \frac{\partial \mathbf{F}}{\partial Q_{k}}=0
$$

Ezzel az eredménnyel a (16) kifejezés a következőképpen írható fel:

$$
\frac{\partial \mathbf{R}}{\partial Q_{k}}=\frac{\partial}{\partial Q_{k}}(\mathbf{P} \mathbf{Q})=\mathbf{P} \frac{\partial \mathbf{Q}}{\partial Q_{k}}
$$

Másrészt

$$
\begin{aligned}
{\left[\frac{\partial \mathbf{R}}{\partial Q_{k}}\right]^{T} } & =\left[\frac{\partial}{\partial Q_{k}}(\mathbf{P Q})\right]^{T}= \\
& =\frac{\partial}{\partial Q_{k}}\left(\mathbf{Q}^{T} \mathbf{P}^{T}\right)=\frac{\partial \mathbf{Q}^{T}}{\partial Q_{k}} \mathbf{P}^{T}
\end{aligned}
$$

Ha a (11), (18) és (19) kifejezéseket behelyettesítjük a (15) egyenletbe, megfelelő rendezés után a következő alakot kapjuk:

$$
\begin{aligned}
\frac{\mathrm{d} U}{\mathrm{~d} \mathbf{Q}} & =2 \sum_{k=1}^{j}\left(\left[\frac{\partial \mathbf{R}}{\partial Q_{k}}\right]^{T} \mathbf{R}\right)= \\
& =2 \sum_{k=1}^{j}\left(\frac{\partial \mathbf{Q}^{T}}{\partial Q_{k}} \mathbf{P}^{T}(\mathbf{P Q}+\mathbf{F})\right)
\end{aligned}
$$

Az U célfüggvény helyi minimumértékét a következő feltételből számítjuk:

$$
\frac{\mathrm{d} U}{\mathrm{~d} \mathbf{Q}}=0,
$$

figyelembe véve, hogy a $\mathbf{Q}$ oszlop $Q_{k}$ szerinti parciális deriváltjai olyan oszlopok, melyeknek elemei, a $k$-dik elem kivételével, amely 1-gyel egyenlő, nullák. A (20) egyenletben elvégzett összegzés következményeképpen a (21) feltétel az alábbi módon írható fel:

$$
\mathbf{P}^{T}(\mathbf{P Q}+\mathbf{F})=0
$$

A fenti egyenlet kifejtett alakja a következő:

$$
\left[\mathbf{P}^{T} \mathbf{P}\right] \mathbf{Q}+\mathbf{P}^{T} \mathbf{F}=0
$$

Vezessük be az alábbi jelöléseket:

$$
\begin{aligned}
& \mathbf{N}=\mathbf{P}^{T} \mathbf{P} \\
& \mathbf{K}=\mathbf{P}^{T} \mathbf{F}
\end{aligned}
$$

Ezzel a (23) egyenlet lineáris lesz Q-ra:

$\mathbf{N Q}+\mathbf{K}=0$

A megoldás Q-ra a következő:

$$
\mathbf{Q}=-\mathbf{N}^{-1} \mathbf{K}
$$

\section{Gyakorlati alkalmazás}

Feltételezzük, hogy az egytengelyü kiegyensúlyozást a gépben létező $O Z$ tengelyre szerelt ellensúlyokkal próbáljuk megvalósítani.

Ebben az esetben az $O X$ és az $O Y$ koordinátatengelyekkel párhuzamos kiegyensúlyozó tengelyek hiányoznak, azaz $F_{X i}=F_{Y i}=0$, tehát az F erők öszszetevői is zérus értékűek: $Q_{i}=R_{i}=S_{i}=T_{i}=0$, $\mathrm{i}=1,2$. 


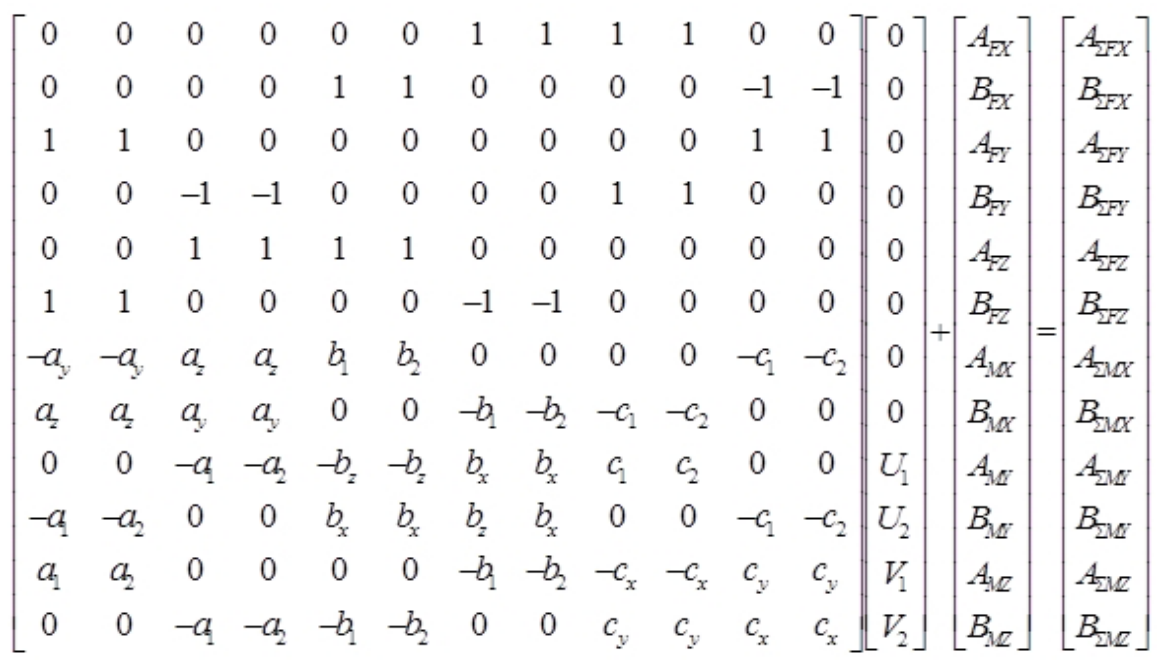

Amint az [1] közlemény is tárgyalja, a mechanizmust terhelő tehetetlenségi erők és ezek nyomatékai egyetlen tengelyre helyezett ellensúlyok beiktatásával nem redukálhatók. A (9) és (10) egyenletek alkalmazásával ezek részben csökkenthetők.

A (6) mátrixegyenlet jobb oldalára a kiegyensúlyozatlanul maradt tehetetlenségi erők és nyomatékok Fourier-együtthatóit írjuk be (28).

Az $O X$ és az $O Y$ koordinátatengelyekkel párhuzamos kiegyensúlyozó tengelyek és ellensúlyaik hiányában az ellensúlyok pozícióit meghatározó koordináták értékei fölöslegessé válnak, ezért nullázzuk ezeket. A (6), (9) és (10) egyenleteket figyelembe véve, a (28) mátrix-egyenlet az alábbi, OZ tengelyre sajátosított (29) alakra hozható.

$$
\left[\begin{array}{l}
\mathbf{A}_{1} \\
\mathbf{A}_{2}
\end{array}\right]\left[\begin{array}{l}
\mathbf{U} \\
\mathbf{V}
\end{array}\right]+\mathbf{F}=\mathbf{F}_{\Sigma}
$$

A (29) egyenlet jelölései a következők:

$$
\begin{aligned}
\mathbf{A}_{1} & =\left(\begin{array}{cccc}
1 & 1 & 0 & 0 \\
0 & 0 & -1 & -1 \\
0 & 0 & 1 & 1 \\
0 & 0 & -c_{1} & -c_{2} \\
c_{1} & c_{2} & 0 & 0
\end{array}\right) \\
\mathbf{A}_{2} & =\left(\begin{array}{cccc}
-c_{1} & -c_{2} & 0 & 0 \\
c_{1} & c_{2} & 0 & 0 \\
0 & 0 & -c_{1} & -c_{2} \\
0 & 0 & -c_{1} & -c_{2} \\
-c_{x} & -c_{x} & c_{y} & c_{y}
\end{array}\right)
\end{aligned}
$$

$$
\begin{aligned}
& \mathbf{U}=\left(\begin{array}{ll}
U_{1} & U_{2}
\end{array}\right)^{T} \\
& \mathbf{V}=\left(\begin{array}{ll}
V_{1} & V_{2}
\end{array}\right)^{T} \\
& \mathbf{F}=\left(\begin{array}{lllll}
A_{F X} & B_{F X} & A_{F Y} & B_{F Y} & A_{M X} \cdots
\end{array}\right. \\
& \left.B_{M X} \quad A_{M Y} \quad B_{M Y} \quad A_{M Z} \quad B_{M Z}\right)^{T} \\
& \mathbf{F}_{\Sigma}=\left(\begin{array}{llll}
A_{\Sigma F X} & B_{\Sigma F X} & A_{\Sigma F Y} & B_{\Sigma F Y} \cdots
\end{array}\right. \\
& A_{\Sigma F Z} \quad B_{\Sigma F Z} \quad A_{\Sigma M X} \quad B_{\Sigma M X} \cdots \\
& \left.A_{\Sigma M Y} \quad B_{\Sigma M Y} \quad A_{\Sigma F Z} \quad B A_{\Sigma M Z}\right)^{T}
\end{aligned}
$$

A (29) egyenletrendszer tíz egyenletből áll és tizennégy ismeretlent tartalmaz. A kérdés ez esetben úgy tevődik fel, hogy hova és mekkora ellensúlyokat kell helyezni a mechanizmus tengelyére ahhoz, hogy az egyenlet jobb oldalán lévő, kiegyensúlyozatlanul maradt erők és nyomatékok abszolút értékei a minimálisra csökkenjenek? Erre a választ a (27), (29), (18) és a (19) egyenletek megoldásával sikerül megszerezni.

\section{Következtetések}

A kiegyensúlyozásnak jelen közleményben ismertetett módszere sok szempontból előnyösebb a hagyományos módszereknél. Az egyenletek felírását meg kell előznie a kiegyensúlyozási feladatban szereplő mechanizmus geometriai és tehetetlenségi feltérképezésének (tömegközéppontok, tehetetlenségi főirányok kiszámítása), ami, a korszerű modellező szoftverek használata mellett, nem jelent akadályt.

A részleges kiegyensúlyozás modelljében szereplő egyenletek száma kisebb, mint az ismeret- 
lenek száma, ami a tervező számára nagyobb szabadságot engedélyez a kiegyensúlyozó tömegek értékének és helyzetének megválasztására.

Habár a jelen közlemény csak a tehetetlenségi erők sorba fejtett alakjának első tagjait tekinti, a módszert általánosítani lehet tetszőleges véges számú sorozattagra, viszont figyelembe kell venni, hogy ez esetben az ismeretlenek száma lényegesen nagyobb lesz, ami nagyobb számítási kapacitást igényel.

\section{Szakirodalmi hivatkozások}

[1] Stevensen E. N.: Balancing of Machines. In: ASME, San Francisco, California, 72/52. (1972).

[2] Papp I., Máté M.: Transformarea generală a două sisteme ortogonale. In: Proceedings CDM 2005, ISBN-973-635-513-6. A IV-a conferinţă de dinamica maşinilor, cu participare internaţională, Braşov, 28-30. mai 2005. Vol. II., 319-326.

[3] Papp I.: Optimization of Dynamical Balancing of Mechanisms According to Diminuation of Vibration Amplitude at a Given Point. In: International Conference in Mechanical Engineering, SatuMare, April 28-May 1, 2005, 285-287. 